\title{
Enforcement Credibility and Frequency of Negotiations in Civil Wars
}

\author{
Hojung Joo and Taehee Whang
}

\begin{abstract}
This article explores the effect of enforcement credibility on the number of negotiations during civil war peace processes. While the use of negotiations during civil wars has increased since the Cold War, there has been a lack of attention to the obstacles faced by conflict parties once negotiations begin. We argue that conflict resolution should be evaluated as a stepwise process, in which factors that increase prospects for agreement enforcement may impact the onset or frequency of negotiations differently. We rely on the international cooperation literature which addresses the relationship between bargaining and enforcement problems. As enforcement becomes more credible, parties engage in bargaining more rigorously in order to make sure the distributive terms are satisfactory. We argue that while the presence of third-party mediators and a negotiating partner with a strong internal support base might increase the likelihood of agreement enforcement, they may also make conflict parties more careful when drafting the agreement, since the cost of revising or breaking the agreement also rises with enforcement credibility. We test the effect of third parties and internal support on the number of negotiations using a zero-inflated negative binomial regression model. We find that the presence of mediators and the presence of a rebel group with a strong support base increase the frequency of negotiations. We also find that factors such as rebel territorial control and Cold War have distinct effects on negotiation onset and not on negotiation frequency, emphasizing the importance of evaluating con-
\end{abstract}

*Hojung Joo(hjjoo@umich.edu) is a Ph.D. student in the Department of Political Science at the University of Michigan. She received her M.A. in Political Science from Yonsei University.

** Taehee Whang(thwhang@yonsei.ac.kr) is a Professor at the Department of Political Science and International Studies at Yonsei University. His work appears at American Journal of Political Science, British Journal of Political Science, International Organization, International Studies Quarterly, and Political Analysis.

This work is based on a master's thesis by Hojung Joo and Taehee Whang's contribution is minor. An earlier version of this work was presented at the Conflict, Peace, Research, and Development workshop (University of Michigan). We thank the participants for their valuable comments. We also thank the three anonymous reviewers whose comments have greatly improved this manuscript. All flaws that remain are the product of our own. This work was supported by the Ministry of Education of the Republic of Korea and the National Research Foundation of Korea (NRF-2016S1A3A2925085) and by Social Science Korea (SSK).

The Korean Journal of International Studies Vol.17, No. 2 (August 2019), 235-266 
flict resolution as a multilevel process.

Key Words: Civil war, Negotiation, Mediation, Third party intervention, Group support, Conflict resolution

\section{INTRODUCTION}

There is great variation in the number of negotiations that conflict parties experience before arriving at conflict termination. During the war in Angola between the People's Movement for the Liberation of Angola (MPLA) and the National Union for the Total Independence of Angola (UNITA), the two parties convened for 14 negotiations in the year 1994 alone prior to producing the Lusaka Protocol. On the contrary, the Abb'a peace agreement between the government of Djibouti and the Front for the Restoration of Unity and Democracy (FRUD) in 1994 ended the civil war with no prior negotiations. Negotiations in Angola and Djibouti both dealt with difficult problems such as rebel disarmament, demobilization, and reintegration (DDR), yet the two dyads differed in how many times they had to reconvene before arriving at conflict resolution. Hence the question - what causes the variation in the number of negotiations that conflict parties experience? Furthermore, what does the number of negotiations tell us about the nature of the given conflict?

Although the civil war literature has paid great attention to negotiation, mediation, and peace agreements, to the best of our knowledge, no work has yet explored the number negotiation attempts as a dependent variable. We believe this is due to two related factors: the lack of consensus in interpreting the number of negotiations, and the lack of theoretical framework that captures the paradoxical nature of negotiations. Frequent negotiations not only embody the willingness of conflict parties to arrive at conflict termination, but also the difficulty that conflict parties face when drawing up the distributive terms of a settlement. Hence, it is tricky to judge if more negotiations always bode well for a given peace process.

We argue that the literature on international cooperation provides a theoretical framework that is applicable to the resolution of civil wars. We argue that the interaction between bargaining and enforcement stages of cooperation asserted by Fearon (1998) provides insight into interpreting the number of negotiations that conflict parties experience before arriving at conflict termination. In order to do so, we assume that negotiations between conflict parties are a form of 
cooperation. ${ }^{1}$ Negotiations reflect the fact that continued warfare is an outcome that both parties want to avoid. However, parties are unlikely to agree with the distributive terms of the agreement, especially if they believe that the agreement will be difficult to break or revise in the future. We also draw from Findley (2013), in which the cost of revision is mentioned as a factor that may increase the difficulty of negotiations. Factors that restrain conflict parties from breaking the agreement in the future make enforcement more credible, but also make conflict parties more hesitant to sign an agreement because if they agree to insufficient terms, it will take more extreme measures to revise them in the future. For example, if the peace agreement was reached in public in the presence of third party mediators, conflict parties will face greater reputation costs and even tangible costs such as economic sanctions if they were to defect from an agreement. In contrast, an agreement that was reached in private without the presence of third party mediators, would make it harder for the conflict parties to break the agreement (credible enforcement). However, at the time of the drafting of the agreement, the parties are aware of this fact and thus become more conservative when agreeing to the distributive terms of the agreement they will make sure they return home with the terms that their constituencies demanded from their leaders, since they do not have the luxury of revising or breaking the already publicized agreement without facing international and domestic backlash.

In this paper, we look at how two factors that can increase the credibility of agreement enforcement can also affect the number of negotiations conflict parties experience before reaching conflict termination - third party intervention and internal constituency support. Third party intervention is known to alleviate enforcement problems faced by parties in intrastate conflict (Lake and Rothchild 1996; Walter 1997). The presence of third parties as a mediator, monitor, peacekeeper, and security guarantor decreases the chances of defection when intrastate warring parties seek cooperation. The costs that a defector must pay becomes more serious if the third party is committed enough to include a security guarantee or conditional sanctions in the agreement; the defector may not only pay reputation costs but experience political and economic

1 "I argue that understanding problems of international cooperation as having a common strategic structure is more accurate and perhaps more theoretically fruitful. Empirically, there are always many possible ways to arrange an arms, trade, financial, or environmental treaty, and before states can cooperate to enforce an agreement they must bargain to decide which one to implement. Thus, regardless of the substantive domain, problems of international cooperation typically involve first a bargaining problem (akin to various coordination games that have been studied) and next an enforcement problem (akin to a Prisoners' Dilemma game)." (Fearon 1998, 270) 
retaliation. Defection is not impossible, but with the presence of various thirdparty mechanisms, it becomes more costly than defecting from bargains struck between conflict parties alone.

We argue that internal qualities of the conflict party, especially the support it receives from its constituencies, is an important factor that affects agreement enforcement. We exploit a selection bias to make this claim. We assume that a group leader, whether it be the leader of the government or the leader of a rebel group, makes a conscious decision that reflects the opinion of her winning coalition. She will only agree to appear at negotiations when she believes that her core supporters agree to such a move. Hence, when we observe a group leader with high popularity arrive at negotiations, we expect a higher likelihood of agreement enforcement compared to when we observe a group leader with low popularity arrive at negotiations. Furthermore, we adhere to the definition provided by Ogutcu-Fu (2016) in defining negotiations, in which a negotiation is only recognized if (a) both parties have agreed to the negotiations and sat down on the same table and (b) they discussed resolution of conflict as a substantive matter. This strengthens the assumption that if a leader has decided to appear at negotiations, the credibility of her enforcing what she had agreed upon will be higher if she is a popular leader. In this paper, we will show how the presence of a third party and the presence of a rebel group with strong support from its constituencies lengthen the bargaining stage of cooperation.

The article proceeds as follows. The next section reviews the literature on negotiations. The second presents a theory which demonstrates the dilemma between resolving enforcement and bargaining problems during civil war peace processes. This section also presents the hypothesis that factors that are believed to alleviate enforcement problems - the presence of third-party mediators and internal constituency support- will lead to higher numbers of negotiations before arriving at conflict termination. The third section explains the data and empirical model employed to test the hypotheses; the fourth section presents the empirical findings. The last section concludes.

\section{LITERATURE REVIEW}

The civil war literature has paid much attention to mechanisms that increase the likelihood of conflict resolution - especially on the occurrence of negotiations. In this section we review the literature on three factors that have been mentioned as making negotiations more likely: power parity, divisibility of stakes, and enforceability of peace agreements. 
Frist, both conflict parties must believe that a quick and easy victory is improbable. The "ripeness" literature presented by Zartman (1989; 1993) argues that negotiations must be preceded by a prolonged stalemate in which both parties lose prospect of a quick and easy victory. Similarly, Bapat (2005) argues that a "window for negotiation" occurs when the insurgents have successfully survived the nascent phase of resistance yet have not grown powerful enough to favor military domination over negotiation with the government. Hultquist (2013) also argue that negotiated settlements and ceasefires are more likely when conflict parties have power parity.

Second, both conflict parties must believe that the stakes are divisible. Indivisibility of stakes hinders negotiations between actors if the conflict revolves around innate and unalterable traits such as ethnicity or race. Notably, Kaufmann (1996) has argued that the only lasting resolution to ethnic conflict is population relocation and partition. He argues that when stakes are indivisible, even when the perceived chance of victory is low, belligerents are driven to fight; victory is the only options that ensures their survival. On the other hand, if the conflict originates from issues that can be reshaped (ideology) or divided (territory), negotiated settlement is a viable choice for conflict parties.

Lastly, factors that alleviate enforcement problems have been argued to increase the likelihood of negotiations. The commitment problem faced by intrastate actors is more severe than that faced by interstate actors, since states usually retain their armies after signing the peace treaty. Since in intrastate conflict at least one party must disarm and demobilize, the party that undergoes the DDR process must withstand a period of intense vulnerability, in which the adversary may exploit to achieve military victory (Walter 1997). Will the government ensure the safety of ex-combatants? Will the rebels demobilize as promised? Will the government accept rebel leaders as legitimate leaders of opposition parties once the new government is installed? Various factors affect an agreement's prospect for enforcement. Changes in alliances, discovery of natural resources, and the occurrence of natural disasters may drastically reshape the power balance between conflict parties. The number of actors involved in the peace process, coupled with problems of actor fragmentation, may increase the risk of agreement breakdown, while factors such as the presence of mediators, peacekeeping forces, and security guarantors can reduce the likelihood of defection. In this paper, we intend to focus on two factors that are known to affect the credibility of agreement enforcement: the presence of third parties and group popular support.

Third parties such as the UN, regional bodies, or individual states may intervene in a civil war militarily, economically, and diplomatically. Results from 
previous literature on the impact of third parties on civil war peace processes are mixed; however, if the third party intervenes with the intent to produce a peace agreement, it is largely accepted that their presence alleviate enforcement problems (Fortna 2004; Sambanis 2000; Beardsley 2011; Crescenzi et al. 2011; Gartner 2011; Svensson 2007; Wallensteen and Svensson 2014; Walter 1997 , 2009). Nonetheless, there is disagreement on how desirable it is for the third party to manipulate the bargaining environment between two conflict parties, since the conflict may recur once the third party departs and leaves behind an enforcement mechanism that cannot be implemented by either conflict parties. If the third party intervenes with the purpose to aid a belligerent, they act to exacerbate enforcement problems faced by conflict parties during a peace process, since the third party can act as a wild card that alters the power balance between belligerents (Balch-Lindsay, Enterline, and Joyce 2008; Findley and Marineau 2015; Findley and Teo 2006; Regan 2002).

The amount of support that a group receives from its constituencies also affects the likelihood of negotiations. Heger and Jung (2017) argue that groups that have a wider base of support also tend to deter spoilers from breaking away from the organization during negotiation processes. They further argue that due to this trait, rebel groups with a wider support base are more likely to draw governments to the negotiating table. Our paper is in line with Heger and Jung (2017) and show that rebels with a wider support base not only bring governments to the negotiating table, but also experience a higher number of negotiations during the peace process precisely due to their enhanced bargaining leverage.

More recent works have not only paid attention to the occurrence of negotiations, but also explored the interdependence of peace processes (Beardsley 2011; Diehl 2006; Doyle and Sambanis 2006; Findley 2013). Factors that increase the likelihood of negotiations may not always the increase the likelihood of a peace agreement or its successful implementation. For example, Findley (2013) shows that while conflicts that experience stalemates do end up at the negotiating table more often, they are also less likely to produce a peace agreement. Similarly, Beardsley (2011) argues that while third-party mediation may increase the likelihood of a peace agreement, agreements produced by third-party mediation are more likely to lead to "fragile" peace that breaks down more easily than their unmediated counterparts.

Our contribution to the negotiation literature is twofold: exploring a previously unexplored dependent variable and demonstrating why variables that affect negotiation frequency differ from those that affect negotiation occurrence by incorporating the IR cooperation literature. Our paper differs from existing 
literature by exploring the frequency of negotiation along with its occurrence. We argue that the frequency of negotiations signal something different from its mere occurrence - while it represents the willingness to talk with the adversary, greater number of negotiations also shows the parties' difficulty of arriving at the distributive terms of the agreement. We theorize that the very mechanisms that incentivize conflict parties to negotiate in the first place, mainly the alleviation of enforcement problems, makes it harder for conflict parties to arrive at an agreement, leading to a prolonged negotiation process.

\section{DETERMINANTS OF NEGOTIATION OCCURRENCE AND NEGO- TIATION FREQUENCY}

While Zartman has argued that a hurting stalemate is a precondition for negotiations, Findley (2013) has shown that conflicts that have experienced stalemates are less likely to reach an agreement or to successfully implement peace. Also, Findley shows that while having multiple actors may incentivize conflict parties to use negotiations as a means to gather information, it may also impede the ability of negotiations to real information about conflict parties, leading to a lower likelihood of agreements being drafted or enforced. According to Findley (2013), factors like stalemates and multiple actors increase actor incentive to gather information via negotiations, but also manifest the innate difficulty of exhausting information problems in the first place, which impede the peace process that follow negotiations.

Findley (2013) also argues that the reason why factors like stalemates lead to prolonged peace processes is because they manifest unresolved information problems. ${ }^{2}$ While we agree that unresolved information problems may stall the peace process, we argue that factors that increase the certainty of enforcement and make "future challenges to the agreement much more difficult" is a key mechanism that prolong the peace process once negotiations begin (Findley 2013, 911).

Adversaries are bound to take the negotiations seriously if they believe that others involved in the drafting of the agreement are willing and able to enforce its terms. If conflict parties are aware that revising or overturning the agreement

2 "Parties recognize that reaching or implementing an agreement could solidify a new status quo, making any future challenges to the agreement much more difficult. Thus, parties will want to be sure that they have fully resolved information problems and attained what they expect based on their capabilities before reaching or implementing a new agreement." (Findley 2013, 911) 
would require greater costs, they will invest more time and energy to make sure they return to their supporters with an acceptable agreement. The bargaining process will become more arduous as parties refuse to draft clauses that could be interpreted against their interests in the future.

The effect of credible enforcement on the number of negotiations can be understood as a result of rational decision making. As the probability of enforcement increases, it compels conflict parties to structure the agreement to maximize their share of the pie. When deciding whether or not to enter talks with an adversary, conflict parties must evaluate five factors: benefit derived from entering talks $\left(b_{1}\right)$, costs incurred by entering talks $\left(c_{1}\right)$, benefits derived from a potential peace agreement $\left(b_{2}\right)$, costs incurred by a potential peace agreement, and the probability of peace agreement enforcement $(e)$.

Figure 1. Player A's Negotiation Calculus

$$
N_{\mathrm{A}}=\left(b_{1}-c_{1}\right)+\left[\left(b_{2}-c_{2}\right) \times e\right]
$$

The components $b_{1}$ and $c_{1}$ demonstrate the costs and benefits incurred by entering talks. Whether the negotiations produce an agreement or not, actors must consider the costs and benefits entailed by the mere act of engaging in talks. Incumbents are generally known to have an aversion to entering talks with rebel groups, as this may not only legitimize the opposition forces but also incentivize other insurgencies to mobilize (Kaplow 2015). On the other hand, some actors may enter talks to appease internal or external audiences. Others may enter talks to gather information from the adversary or from third-party mediators. Negotiations that are motivated by aforementioned factors may be considered "insincere" as at least one conflict party is not interested in drafting an enforceable agreement. According to Figure 1, if $e$ approaches o, actors will devote less attention to entering talks, as there is little to gain or lose from entering "insincere" talks. "Insincere" negotiations are used by actors as a mere tool to gain information about the opponent, to signal resolve and legitimacy to internal and external audiences, or to simply to buy time.

However, if actors perceive that the talks would produce an enforceable agreement, they will be incentivized to pay attention to the distributive terms of the peace agreement. As $e$ approaches 1, negotiations become an extension of the battlefield in which adversaries utilize their bargaining leverage to claim as much distributive gains as possible. $N_{\mathrm{A}}$ therefore, signifies the stakes involved in negotiations. Once the value of $N_{\mathrm{A}}$ increases, actors will not only devote more time and energy to negotiations, but also refuse to settle before maximizing gains. 
We argue that the probability of enforcement, $e$, is largely affected by two factors: internal and external commitment towards the peace process. If the conflict party has a broad support base, it will be more likely for the group to follow and enforce the terms than if the group had a hard time garnering voluntary support from its constituencies. Once the conflict party decides to engage in negotiations, its popularity will convince the counterpart that the agreement has a higher likelihood of enforcement, ceteris paribus. Regarding external commitment, we argue that if third parties are present and interested in producing a peace agreement, parties involved in negotiations will expect a higher likelihood of agreement enforcement.

\section{THIRD PARTY HYPOTHESIS}

Third party intervention has been discussed as one of the few options available to alleviate enforcement problems faced by parties in civil wars (Walter 2002, 2009; Fortna 2004). Third-parties impact various stages of the peace process, as they can deploy troops and monitoring personnel to oversee the implementation of the agreement and punish defectors through economic and military coercion. At the very least, they can "name and shame" the defector and incur reputation costs upon the defector (Hafner-Burton 2008) The presence of a third party as a mediator, monitor, peacekeeper, or security guarantor decreases the chance of defection. While defection is not impossible, the presence of various third-party enforcement mechanisms increases the cost of defecting from an agreement.

Case studies show that the involvement of external increase the number of negotiations in a civil war peace process. During the Mozambique peace process of 1992, the UN, having failed to ensure agreement enforcement in neighboring Angola, was resolute enough to push for disarmament and demobilization of rebels before elections. The number of peacekeeping forces deployed by the UN Operation in Mozambique (ONUMOZ) was over 9,00o including 6,625 troops; this was staggering compared to the 350 military advisors deployed a year before in Angola. Even with such resolve and commitment shown by third party enforcers, the peace process faced numerous risks of failure. Even after ten rounds of talks and the granting of observer status to France, Portugal, UK, US, and the UN, it took three more rounds of negotiations over the course of four months to convince both sides to sign the peace agreement. During the final few months, mediators had to compel conflict parties to agree upon the size of the new army and the status of the State Information and Security Service (SISE) (Henderickson and Vines 1998). Prospects for producing an enforceable 
agreement made the actors more cautious and hesitant in finalizing its terms.

Similarly, adversaries in the Tajikistan civil war were pressed to find a negotiated settlement after the UN became actively involved in September 1992. By 1994 both parties were already disillusioned with the prospect for an easy military victory, but negotiations dragged on until June 1997 because parties could not agree upon key issues such as joint governance and power-sharing. Oftentimes, increased enforcement credibility caused by third-party enforcers not only exacerbate tensions during negotiations, but also amp up the level of violence in the battlefield as parties try to increase their bargaining leverage. Violence in Ukraine increased drastically in February 2015 as prospects for a ceasefire became clearer at the time, with the involvement of France, Germany, and US pushing for a resolution. Mounting pressure from the US for a ceasefire ironically intensified the fighting in Ukraine, triggering "the last push".

We expect the number of negotiations to rise as third parties interested in producing a peace agreement enter the peace process. Conflict parties become aware that the agreement produced by the talks would now be trickier to undo or revise, as more actors become invested invest in maintaining peace. To proxy for third parties interested in maintaining post-conflict peace, we look for the presence of a third-party mediator during talks and the presence of a peacekeeping force in a given dyad-year.

Hypothesis 1 (Third party hypothesis): Conflict parties will experience more negotiations if a third party is present in the conflict resolution process.

\section{INTERNAL SUPPORT HYPOTHESIS}

Another factor that affects the prospects for agreement enforcement and consequently on the number of negotiations is the amount of support an actor receives from its own constituency. Heger (2015) finds that groups that utilize violence against civilians have low constituency support. Moreover, Heger and Jung (2017) argue that groups that engage in service provision to their constituencies are less likely to be affected by the spoiler problem. They argue that groups that provide service to their constituencies are "more capable of credibly committing to negotiation processes," and because they are better at committing to an agreement, "governments are more interested in negotiating with groups capable of controlling potential extremists." (Heger and Jung 2017, 1205).

Our internal support hypothesis is in line with Heger and Jung (2017). We argue that groups that are better able to mobilize without resorting to violence 
against their own supporters will be more successful at bringing the government to the negotiating table, but also more likely to experience more negotiations before arriving at conflict termination. The very trait that makes the rebel group a more representative and reliable enforcer also makes the government careful when drafting the agreement. Compared to dealing with a rebel group with a weak support base, the government would have to experience more backlash and resistance from the rebel group if it tried to revoke previously agreed terms.

We argue that a groups' support base has a distinct effect on bargaining leverage, one that remain significant even after controlling for the rebel groups' relative military power. Hence, we control for the rebel groups' relative military strength when testing the hypothesis that the rebel groups' popular support increases the likelihood of negotiations but also increases the number of negotiations that the conflict parties experience. We also control for the number of conflict parties involved in the conflict itself to account for the "spoiler effect" that could contribute to the increase in the number of negotiations (Findley 2013).

Both the third-party hypothesis and internal support hypotheses work through the same mechanism - they believe that the product of negotiations will be more likely to be enforced, turning them into pickier negotiators. The increase in the number of negotiations is manifestation of this change in perception.

Hypothesis 2 (Internal support hypothesis): Conflict parties will experience more negotiations if they have a broader support base.

\section{DATA AND RESEARCH DESIGN}

We use dyad-year data on civil war negotiations from Ogutcu-Fu (2016). The coding of negotiations suits our goal well, as Ogutcu-Fu (2016) only codes negotiations in which (1) both conflict parties agreed to the talks and sat at the same table and (2) resolution of the conflict was discussed as a substantive issue. This coding rule sufficiently excludes "insincere" talks from the dataset as it only codes negotiations in which parties have recognized each other as a legitimate bargaining partner and has discussed the resolution of conflict during the talks. The dataset covers intrastate armed conflicts between 1980 and 2005, using the conventional 25 deaths per year as a threshold for coding civil conflict. We added data on the presence of peacekeeping forces from Mullenbach (2013) and the identity of mediators by referring to DeRouen et al. (2011) and Nexis Uni. We utilize 1411 dyad-year observations from Ogutcu-Fu, which includes no missing data for our analysis, except for the Battle Death (log) variable as logging the 
Battle Death variable resulted in NA entries. We imputed NA values for Battle Death $(\log )$ variable with os for our main analysis, but also conducted a separate test without imputation, as shown in Table A2. The imputation does not change our substantive results. The summary statistics for our analysis is presented below.

Table 1. Summary Statistics

\begin{tabular}{lllllc}
\hline \multicolumn{1}{c}{ Variable } & Mean & S.D. & Min & Max & N \\
\hline Number of negotiations & 0.428 & 1.284 & 0 & 15 & 1411 \\
Number of negotiations (lag)* & 0.296 & 1.068 & 0 & 15 & 1411 \\
Mediation (lag) & 0.075 & 0.264 & 0 & 1 & 1411 \\
Mediation by UN (lag) & 0.025 & 0.156 & 0 & 1 & 1411 \\
Mediation by organization (lag) & 0.028 & 0.164 & 0 & 1 & 1411 \\
Mediation by state (lag) & 0.028 & 0.164 & 0 & 1 & 1411 \\
Mediation by individual & 0.029 & 0.168 & 0 & 1 & 1411 \\
Peacekeeping & 0.155 & 0.362 & 0 & 1 & 1411 \\
Peacekeeping (lag) & 0.111 & 0.314 & 0 & 1 & 1411 \\
Government support & 0.403 & 0.323 & 0 & 1 & 1411 \\
Rebel support & 1.103 & 0.667 & 0 & 2 & 1411 \\
Rebel territorial control & 0.369 & 0.483 & 0 & 1 & 1411 \\
Lootable resources & 0.184 & 0.387 & 0 & 1 & 1411 \\
Number of actors & 1.038 & 1.249 & 0 & 5 & 1411 \\
Ethnic fractionalization & 0.611 & 0.221 & 0.039 & 1 & 1411 \\
Cold War & 0.359 & 0.48 & 0 & 1 & 1411 \\
Parity & 0.045 & 0.207 & 0 & 1 & 1411 \\
Battle deaths (log)** & 3.201 & 3.026 & 0 & 10.33 & 830 \\
Conflict duration (log) & 7.442 & 1.571 & 0 & 9.94 & 1411 \\
\hline Note: Variables that wer & & 0 & 0 & 1 \\
\hline
\end{tabular}

Note: * Variables that were lagged were lagged by 1 year. ${ }^{* *}$ Logging battled death variable resulted in 581 missing values, as log (0) returns an NA. We replaced NA entries with 0 for the main analysis performed in Table 2 and Table 4. As presented in Table A2, dropping NA observations does not change our results.

We used a zero-inflated negative binomial regression model since the distribution of our variable of interest, the number of negotiations in a given dyad-year, was heavily skewed towards the right. Furthermore, zero-inflated negative binomial model was chosen over negative binomial model due to the prevalence of "o" negotiation attempts. Out of 1,411 conflict-dyad-year observations in our main model, only 259 observations had non-zero negotiation attempts. The Vuong test resulted in a Z score of 5.399, supporting our selection of the zero-inflated model. We used a logistic model for our zero-inflated model and clustered standard errors around each dyad. The model first evaluates 
whether the variables affect the adversaries' decision to sit at negotiations (logit) and then utilizes the negative binomial model to evaluate the effect of the same variables on the number of negotiations (using the non-zero dyadyear observation). This approach is in line with the existing bargaining literature in which factors that affect negotiation onset affect negotiation outcomes differently (Clayton and Gleditsch 2014; Findley 2013; Greig and Regan 2008).

Figure 2. Number of Nonzero Negotiations

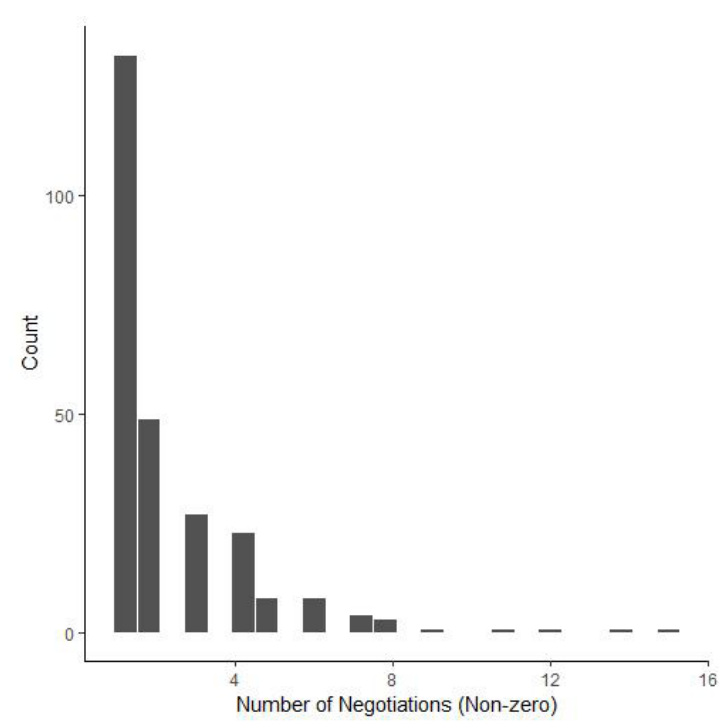

The presence of third parties is measured by a dummy variable indicating whether the negotiations were mediated by a third party. At first, we looked at whether the presence of any third-party mediator influenced the number of negotiations by lumping the mediator variable regardless of the identity of the mediator. In our second test we also evaluate the identity of the mediator by looking at whether the mediation was conducted by the UN, a regional organization, a third-party state, or an individual. A single dyad-year can have multiple types of mediator sit at negotiations, and we coded them as separate dummy variables after referring to DeRouen et al (2011) and articles from Nexis Uni. All mediation variables were lagged one year to avoid the problem of reverse causation, in which the number of negotiations in the previous year affect the third-party mediators' decision to intervene. Another proxy for the presence of third parties is the presence of peacekeeping forces before and during negotiations. Although it is commonplace 
for peacekeeping missions to be deployed after the signing of a ceasefire or a peace agreement, some are deployed while negotiations occur. The variable was also lagged one year to avoid the problem of reverse causation.

Group support was measured for both the government and the rebel in a given dyad-year. Government support was measured by "vote share of the leading government party," while rebel support was measured by a composite index taken from Ogutcu-Fu (2016), which adds two binary indicators measuring group mobilization capacity (Cunningham et al. 2013) and one-sided violence against civilians (Eck and Hultman 2007). Group mobilization is coded as "high" or "low" based on the groups' ability to mobilize personnel relative to the government, while group violence is coded as " 1 " if the group deliberately killed 25 or more civilians for two consecutive years within a given conflict period. Rebel constituency support captures both the rebel groups' capacity to mobilize and the nature of such mobilization (voluntary or coerced).

Other variables that may affect negotiations, such as power parity, conflict duration, cumulative battle deaths, ethnic fractionalization, rebel territorial control, lootable resources, and whether or not the war occurred during the Cold War, were included as control variables. Power parity, in line with the literature on stalemates, should increase the likelihood of negotiations. Conflict duration and battle deaths may also increase the likelihood of negotiations but may contribute to prolonged negotiation processes as protracted and brutal wars leave deeper wounds that require more time for parties to heal. Ethnic fractionalization may impede cooperation but may also be unrelated to negotiations once factors such as power parity or group support are controlled for. Rebel territorial control is used to evaluate whether groups that hold territory affect negotiations differently than those that do not. This measure is different from power parity, which evaluates relative manpower between the government and the respective rebel group. The presence of lootable resources such as oil, diamonds, poppies, and other lucrative materials are known to affect conflict dynamics in various ways. The presence of oil increases the likelihood of conflict (especially separatist conflict), while diamonds and drugs prolong existing conflict (Ross 2004). It might be possible that the presence of lootable resources also lead to more negotiations, as the distribution of these resources may impede the progress of these talks. The question of who will control the mines and reserves will become an issue of intense contention. The Cold War variable is used to control for changes in third party motivation to intervene in intrastate conflict (Kalyvas and Balcells 2010). We also lag the number of negotiations by one year, since the occurrence of negotiations in a given year is likely to affect the number of negotiations in the next year. 
Enforcement Credibility and Frequency of Negotiations in Civil Wars | 249

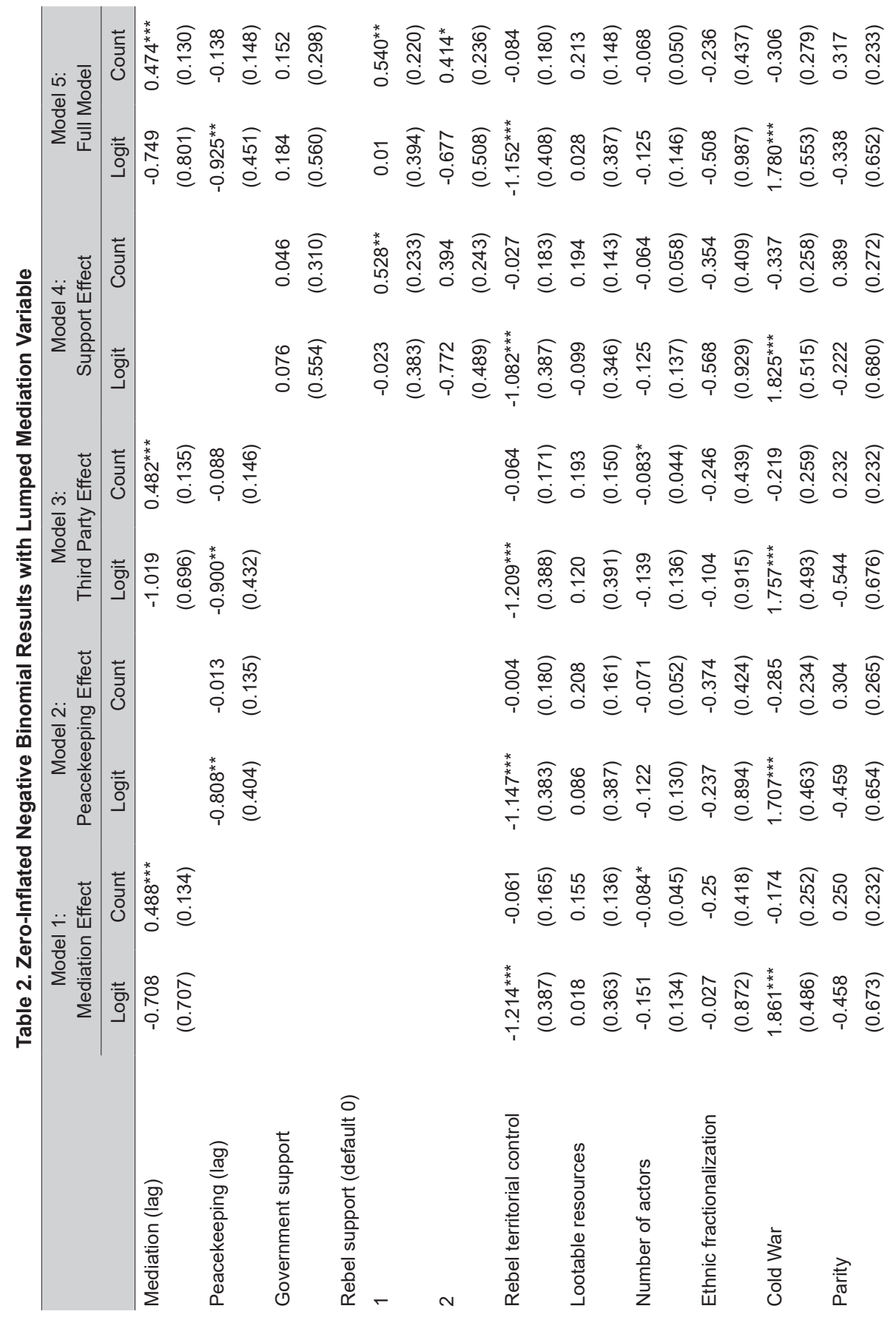




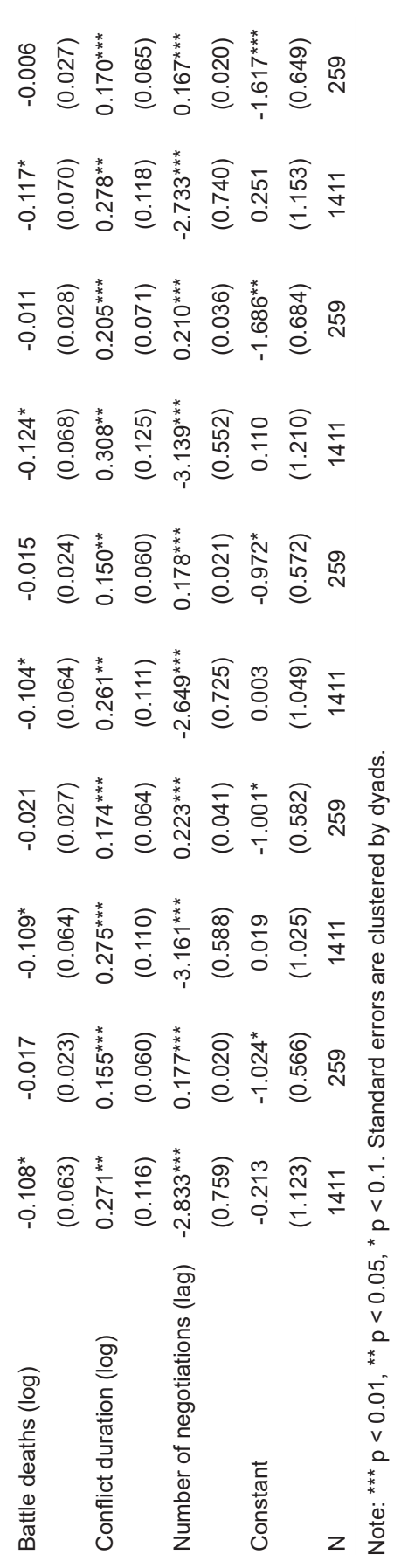




\section{RESULTS}

The estimates produced by the zero-inflated negative binomial analysis is presented in Table 2. Models 1 to 3 evaluate whether the presence of a thirdparty, whether it be in the form of a mediator or a peacekeeping force, increases the number of negotiations. Model 4 adds the government and rebel internal support variables into the analysis, resulting in the full model.

The results for testing the third-party hypothesis are mixed. The presence of a third-party mediator increased the number of negotiations once adversaries decided to engage in talks. Even when controlling for variables known to impede cooperation between adversaries, such as ethnic fractionalization, battle deaths, conflict duration, and number of actors involved, the presence of a third-party mediator shows a positive and statistically significant relationship with the number of negotiations across all models. The Mediation (lag) variable at the inflation stage shows a negative sign with the non-occurrence of talks, hinting at a possible positive impact that past mediations have on future negotiation onsets - this is intuitive, since mediators are generally expected to increase the likelihood of negotiations. However, the correlation does not reach conventional levels of statistical significance.

We see a similar behavior for the Peacekeeping (lag) variable in the inflation stage of the analysis, in which dyads that had peacekeepers deployed in the past seem to have a higher likelihood of starting negotiations (reduced likelihood of non-occurrence). The positive effect that peacekeeping has on the occurrence of negotiations is consistent throughout the model, even when replacing the Peacekeeping (lag) variable with a non-lagged variable (Table A1), and even after evaluating the dataset without replace NA with o's (Table A2). Table A1 shows that the Peacekeeping variable also has a positive correlation with the number of negotiations, reinforcing our hypothesis that while third party presence might increase the likelihood of negotiation onset, it might also prolong the negotiation process.

What is interesting is that the presence of peacekeepers seems to have no effect on the number of negotiations in the negative binomial stage of the analysis. After testing without lagging the peacekeeping variable (Table A1), we found that the Peacekeeping variable does increase the number of negotiations once they begin, but that its effect on the number of negotiations is unclear (Table A2). These tests provide two possible explanations for why the peacekeeping variable does not show significance in the count stage of the full model. First, the effect (if any) of peacekeeping per se has a shorter timespan (less than a year) than that of mediators. Second, the conflict parties think of peacekeepers as a product of 
third-party mediation, hence the effect of peacekeeping forces are confounded by the presence of mediators. Exploring how conflict parties perceive peacekeepers, either as an enforcer of its own or as a by-product of another mediating force is beyond the scope of this paper, but we believe that the effect of peacekeepers on the number of negotiations are absorbed by the effect of mediators.

The second hypothesis concerning the effect of actor constituency support also show mixed results, as the number of government party seats do not have any effect on either the logit or count models. This may be because the vote share of the leading government party is an incomplete proxy for measuring government constituency support. The countries included in our dataset had to be in active conflict with a rebel group - it is difficult to take election results during wartime at face value, especially if these areas were affected by political and economic backwardness before the war. On the other hand, the rebel constituency support variable shows a positive relationship with the number of negotiations once talks begin. The results give weight to our hypothesis that once groups enter talks, those with a greater capacity to mobilize and maintain voluntary support experience more talks before arriving at conflict termination. The government becomes more careful when engaging in talks with rebel groups that are popular, as the decisions made in the talks would be taken more seriously by the public. A more popular and capable negotiating partner not only makes agreement enforcement more credible, but also raises the cost of breaking or revising the agreement in the future, making both parties patient when drafting the agreement in the first place.

Table 3. Summary of Effects on Negotiation Onset and Frequency

\begin{tabular}{ccc}
\hline & + & - \\
\hline Negotiation onset & Peacekeeping (lag) & Conflict duration (log) \\
& Cold war \\
& Rebel territorial control & \\
& Battle deaths (log) & \\
Number of negotiations (lag) & \\
Megotiation frequency & Mediator (lag) & \\
& Rebel support & \\
& Conflict duration (log) \\
& Number of negotiations (lag) \\
\hline
\end{tabular}

The controls that show statistical significance for the inflation model are: Rebel territorial control, Cold War, Battle deaths (log), Conflict duration (log), and Number of negotiations (lag). Dyads in which rebel groups have the capacity to hold territory seem less likely to observe non-occurrence of talks; in other words, more likely to engage in talks in the first place. As rebel groups demonstrate 
their capacity to capture and retain territory, they can no longer be ignored by the government as mere bandits, leading to higher likelihood of negotiation onset. Dyads that existed during the Cold War had a lower chance of entering negotiations. This might be because as proxies, the conflict parties could not decide on negotiations without the approval of their patrons, making it difficult for conflict parties to initiate talks. This is manifest in the explosion of peace negotiations with the fall of the Soviet Union (Hironaka 2005), a phenomenon that may have also led to different form of warfare that may be more conducive to negotiations (Kalyvas and Balcells 2010, 426). For Battle deaths (log), there is a weak yet negative correlation between the variable and the non-occurrence of talks. Albeit weakly, the results reinforce the "war-weariness" and "ripeness" literature, in which citizens who become weary of the ongoing atrocities of war become more open to the possibility of a negotiated peace.

On the other hand, Conflict duration (log) variable shows a strong and negative relationship with the possibility of talks, while also prolonging the peace process once it does begin. When it comes to the duration of conflict, older conflicts had a harder time initiating talks than did shorter ones. The contradictory relationship between conflict duration and battle deaths on the onset of negotiations warrants a more nuanced theory on "war-weariness", as our results suggest that wars that are short yet bloody may have completely different prospects for starting negotiations than wars that are less violent yet protracted. Perhaps longer conflicts consolidate the cleavage between conflict parties, enforcing the "us" and "them" mentality, while giving time for conflict parties and civilians to get adjusted to living alongside conflict, providing less incentive for conflict parties to seek resolution. Explaining the count stage of the model follows a similar logic. The longer the parties have engaged in warfare, the more issues they need to solve - it is unsurprising that conflict duration shows a positive relationship with the frequency of negotiations. Previous negotiations show a strong and positive relationship with the initiation of talks, and a strong positive relationship with their frequencies. Conflict parties that have had experience with talks in the past were more inclined to engage in one in the future and was more likely to participate in more frequent talks.

Note, however, the in Table 2 we did not explore the identity of the mediators. In Table 4, we present the same test with the Mediation (lag) variable categorized into the identity of the mediator: UN, regional organization, state, or individual. In Model 5 in Table 4, we find that all types of third-party mediated talks, with the exception of those mediated by individuals, increase the frequency of negotiations once they begin. Interestingly, we find that while UN mediations increase the likelihood of talks occurring again in the following 
year (count stage), dyad-years that experienced UN mediation the year before was less likely to enter talks in the following year (inflation stage). On the other hand, talks that were mediated by mediators with individual status - in our dataset these are former presidents and prime ministers of global and regional powers, such as Clinton and Mandela, conflict parties were more likely to enter talks. Rather than attributing the blame on UN mediators, we argue that this may signal a selection effect. Talks initiated by the UN are larger in scope and produce agendas that require more than a year to complete. Since UN talks have already launched subsequent projects such as the deployment of peacekeepers and the preparation for elections, there is no need for another talk between conflict parties for at least another year. Perhaps another explanation is that UN mediators usually enter the scene when conflict is nearing its end, and where individual-level and regional-level mediators have made progress early on.

In Table 4, one of our Rebel support variables loses its statistical significance, but the sign remains positive. The relationship between our dependent variable and variables that showed significance in Table 2 maintain their significance and signs in Table 4. 
Enforcement Credibility and Frequency of Negotiations in Civil Wars | 255

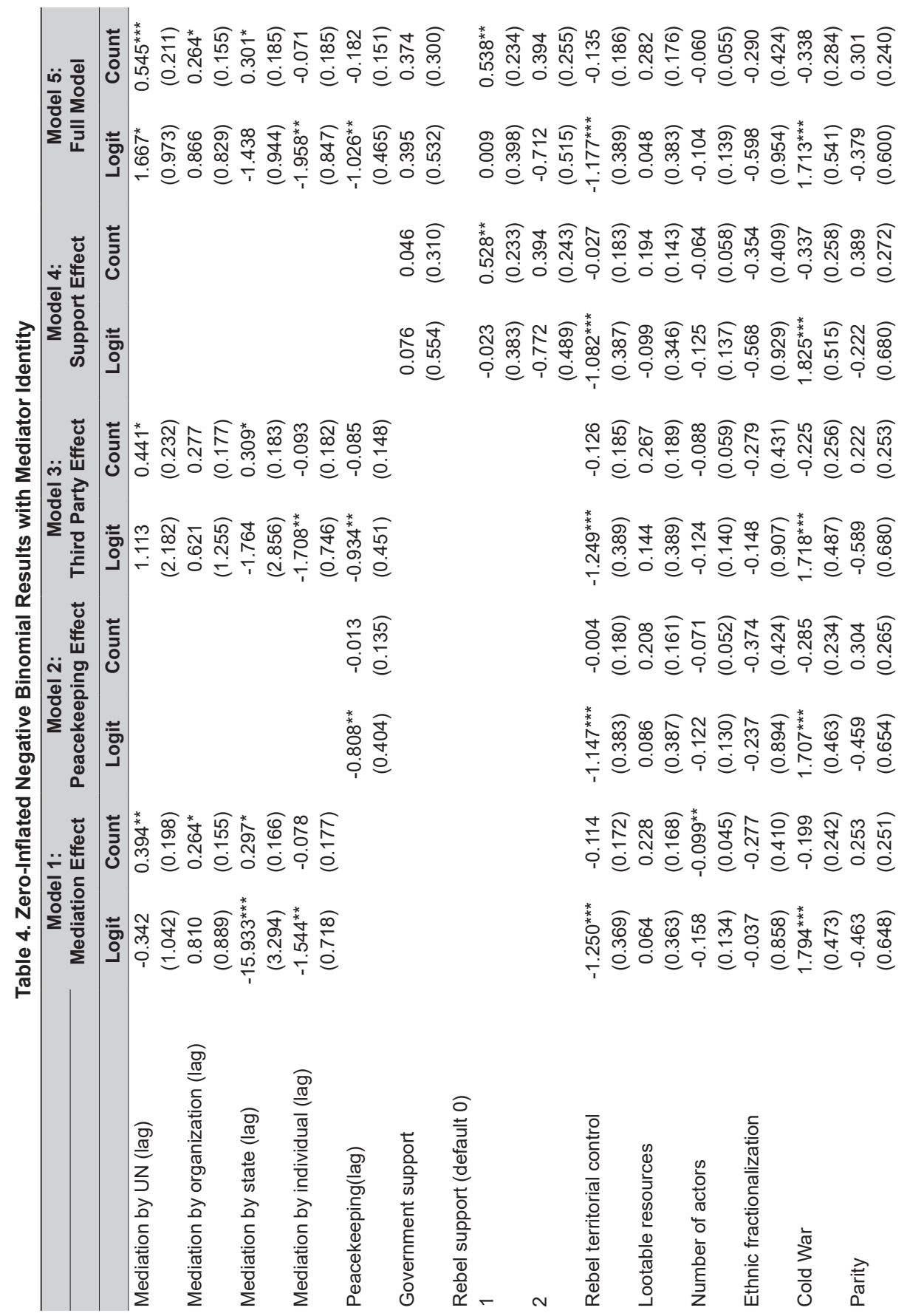




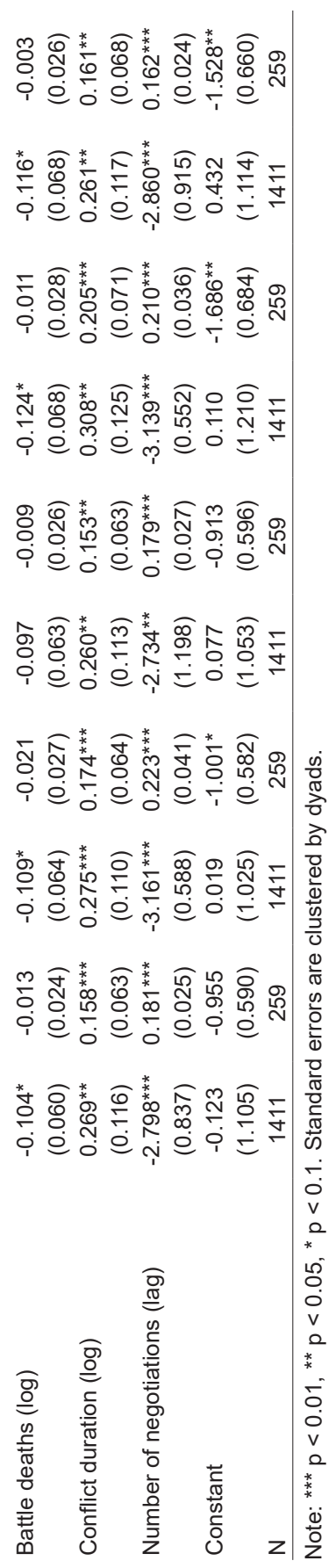


In general, our results verify the existence of a trade-off between enforcement credibility and the number of negotiations in the context of civil wars. The presence of a mediator increased the frequency of negotiations once the talks began, and the presence of a popular and well-supported rebel group as a negotiating partner also increased the frequency of talks. These factors made conflict parties anticipate the enforcement of the product of these talks, making them more careful when drafting the terms of the peace to come.

\section{CONCLUSION}

This article provides insight on the determinants of the frequency of negotiations that conflict parties experience during peace processes. Furthermore, we show how factors known to affect the initiation of negotiations do not always affect the frequency of negotiations the same way. Why do some conflicts experience more negotiations than others? And how do factors that are known to be important in the peace process, such as third-party intervention and rebel internal constituency support, affect the number of talks that the conflict parties choose to join?

Relying on Fearon (1998) and Findley (2013), we argue that in civil war peace processes, mechanisms that increase agreement enforceability increase the number of negotiations before an agreement is reached, by motivating adversaries to "bargain harder" for better gains. Zero-inflated negative binomial regression results, presented in Table 2 and Table 4, support this argument. Even when controlling for various factors such as prior experience with negotiations, power parity, number of actors, and ethnic fragmentation, the presence of a third-party mediator and the degree of rebel internal support increased the number of negotiations attempted in a given dyad-year.

The outcome of the 2016 Colombian peace referendum manifests this dilemma. After four years of talks, citizens of Colombia failed to arrive at consensus over whether or not to strike a peace deal with the Revolutionary Armed Forces of Colombia People's Army (FARC). Even with unprecedented international support and attention, citizens rejected the peace deal not because they feared that the deal would be broken, but because they found the specific terms of the agreement unsatisfactory (Weiner 2016).

Other decade-old conflicts that still struggle to settle upon the distributive terms of the agreement. Adversaries of South Sudan's civil war, waged since 2013, produced a peace deal in August 2015, but President Salva Kiir and opposition leader Reik Machar still could not settle on the composition of a transitional government. Talks dragged on for months, but the peace deal was pushed forward by the threat of UN sanctions, despite government reservations on key distributional issues. 
Aware that third parties are capable of enforcing the agreement, both parties were hesitant to design distributional terms which were likely to be irrevocable. The incomplete agreement soon broke down, since both leaders discarded a peace deal that pushed aside substantial distributional issues as "reservations." The failure of South Sudan's August 2015 peace agreement was not due to the lack of ability or willingness to enforce the terms, but rather the inability of conflict parties to figure out how to divide the pie; this is a classic example of enforcement credibility lengthening the negotiation stage of a peace process.

This article presents evidence that factors that are known to resolve enforcement problems may affect the peace process in unexpected ways. Increased enforcement credibility, whether it be due to third party intervention or strong internal support, trouble negotiators with issues of justice and division - questions that did not concern them when the question of enforcement was uncertain. Future research may explore tools that alleviate bargaining problems, while preserving the enforcement credibility of the general cooperation process.

\section{REFERENCES}

Balch-Lindsay, Dylan, Andrew J. Enterline, and Kyle A. Joyce. 2008. "ThirdParty Intervention and the Civil War Process." Journal of Peace Research 45(3), 345-363.

Bapat, Navin A. 2005. "Insurgency and the Opening of Peace Processes." Journal of Peace Research 42(6), 699-717.

Beardsley, Kyle. 2011. The Mediation Dilemma. Cornell University Press.

Clayton, Govinda, and Kristian Skrede Gleditsch. 2014. "Will We See Helping Hands? Predicting Civil War Mediation and Likely Success." Conflict Management and Peace Science 31(3), 265-284.

Crescenzi, Mark J. C., Kelly M. Kadera, Sara McLaughlin Mitchell, and Clayton L. Thyne. 2011. "A Supply Side Theory of Mediation." International Studies Quarterly 55(4), 1069-1094.

Cunningham, D. E., Gleditsch, K. S., and Salehyan, I. 2013. "Non-State Actors in Civil Wars: A New Dataset." Conflict Management and Peace Science 30(5), 516-531.

DeRouen Jr, K., Bercovitch, J., and Pospieszna, P. 2011. "Introducing the Civil Wars Mediation (CWM) Dataset." Journal of Peace Research 48(5), 663-672.

Diehl, Paul F. 2006. "Just a Phase? Integrating Conflict Dynamics Over Time." Conflict Management and Peace Science 23(3), 199-210.

Doyle, Michael W., and Nicholas Sambanis. 2006. Making War and Building Peace: United Nations Peace Operations. Princeton, N.J: Princeton University Press. 
Eck, Kristine, and Lisa Hultman. 2007. "One-Sided Violence Against Civilians in War: Insights from New Fatality Data." Journal of Peace Research 44(2), 233-46.

Fearon, James D. 1998. "Bargaining, Enforcement, and International Cooperation." International Organization 52(2), 269-305.

Findley, Michael G. 2013. "Bargaining and the Interdependent Stages of Civil War Resolution." Journal of Conflict Resolution 57(5), 905-932.

Findley, Michael G., and Josiah F. Marineau. 2015. "Lootable Resources and Third-Party Intervention into Civil Wars." Conflict Management and Peace Science 32(5), 465-486.

Findley, Michael G., and Tze Kwang Teo. 2006. "Rethinking Third-Party Interventions into Civil Wars: An Actor-Centric Approach." The Journal of Politics 68(4), 828-837.

Fortna, Virginia Page. 2004. "Does Peacekeeping Keep Peace? International Intervention and the Duration of Peace After Civil War." International Studies Quarterly 48(2), 269-292.

Gartner, Scott Sigmund. 2011. "Signs of Trouble: Regional Organization Mediation and Civil War Agreement Durability." The Journal of Politics 73(2), 380-390.

Greig, J. Michael, and Patrick M. Regan. 2008. "When Do They Say Yes? An Analysis of the Willingness to Offer and Accept Mediation in Civil Wars." International Studies Quarterly 52(4), 759-781.

Hafner-Burton, Emilie M. 2008. "Sticks and Stones: Naming and Shaming the Human Rights Enforcement Problem." International Organization 62(4), 689-716.

Heger, Lindsay L. 2015. "Votes and Violence: Pursuing Terrorism while Navigating Politics." Journal of Peace Research 52(1), 32-45.

Heger, Lindsay L., and Danielle F. Jung. 2017. "Negotiating with Rebels: The Effect of Rebel Service Provision on Conflict Negotiations." Journal of Conflict Resolution 61(6), 1203-1229.

Hendrickson, Dylan, and Alex Vines, eds. 1998. The Mozambican Peace Process in Perspective. Vol. 3. The Accord Series. London: Conciliation Resources.

Hironaka, Ann. 2005. Neverending Wars: The International Community, Weak States, and the Perpetuation of Civil War. Cambridge, MA: Harvard University Press.

Hultquist, Philip. 2013. "Power Parity and Peace? The Role of Relative Power in Civil War Settlement.” Journal of Peace Research 50(5), 623-634.

Kalyvas, Stathis N., and Balcells, Laia. 2010. "International System and Technologies of Rebellion: How the End of the Cold War Shaped Internal Conflict." American Political Science Review 104(3), 415-429. 
Kaplow, Jeffrey M. 2015. "The Negotiation Calculus: Why Parties to Civil Conflict Refuse to Talk." International Studies Quarterly 6o(1), 38-46.

Kaufmann, Chaim. 1996. "Possible and Impossible Solutions to Ethnic Civil Wars." International Security 20(4), 136-175.

Lake, David A. and Rothchild, Donald. 1996. "Containing Fear: The Origins and Management of Ethnic Conflict." International Security 21(2), 41-75.

Mullenbach, Mark. J. 2013. "Third-party Peacekeeping in Intrastate Disputes, 1946-2012: A New Dataset.” Midsouth Political Science Review 14(1), 103-133.

Ogutcu-Fu, Sema H. 2016. "Outside the Battlefield: In-Group Political Dynamics of Civil Conflict Negotiations and Settlements." Political Research Quarterly 69(3), 403-417.

Regan, Patrick, M. 2002. "Third-Party Interventions and the Duration of Intrastate Conflicts." Journal of Conflict Resolution 46(1), 55-73.

Ross, Michael L. 2004. "What Do We Know about Natural Resources and Civil War?" Journal of Peace Research 41(3), 337-356.

Sambanis, Nicholas, and Elbadawi, Ibrahim A. 2000. External Interventions and the Duration of Civil Wars. Policy Research Working Papers. The World Bank.

Stedman, Stephen John. 1997. "Spoiler Problems in Peace Processes." International Security 22(2), 5-53.

Svensson, Isak. 2007. "Bargaining, Bias and Peace Brokers: How Rebels Commit to Peace." Journal of Peace Research 44(2), 177-194.

Wallensteen, Peter, and Isak Svensson. 2014. "Talking Peace: International Mediation in Armed Conflicts." Journal of Peace Research 51(2), 315-327.

Walter, Barbara F. 1997. "The Critical Barrier to Civil War Settlement." International Organization 51(3), 335-364. . 2002. Committing to Peace: The Successful Settlement of Civil Wars. Princeton University Press. . 2009. "Bargaining Failures and Civil War." Annual Review of Political Science 12(1), 243-261.

Weiner, Katie. 2016. "Colombia's Uncertain Future in the Wake of the Peace Referendum." Harvard Political Review (Oct 9). Accessed at http:// harvardpolitics.com/world/farcdeal (August 8, 2019).

Zartman, I. William. 1989. Ripe for Resolution: Conflict and Intervention in Africa. New York: Oxford University Press. . 1993. "The Unfinished Agenda: Negotiating Internal Conflicts." In Roy Licklider ed., Stopping the Killing: How Civil Wars End, New York: New York University Press, 20-34. 


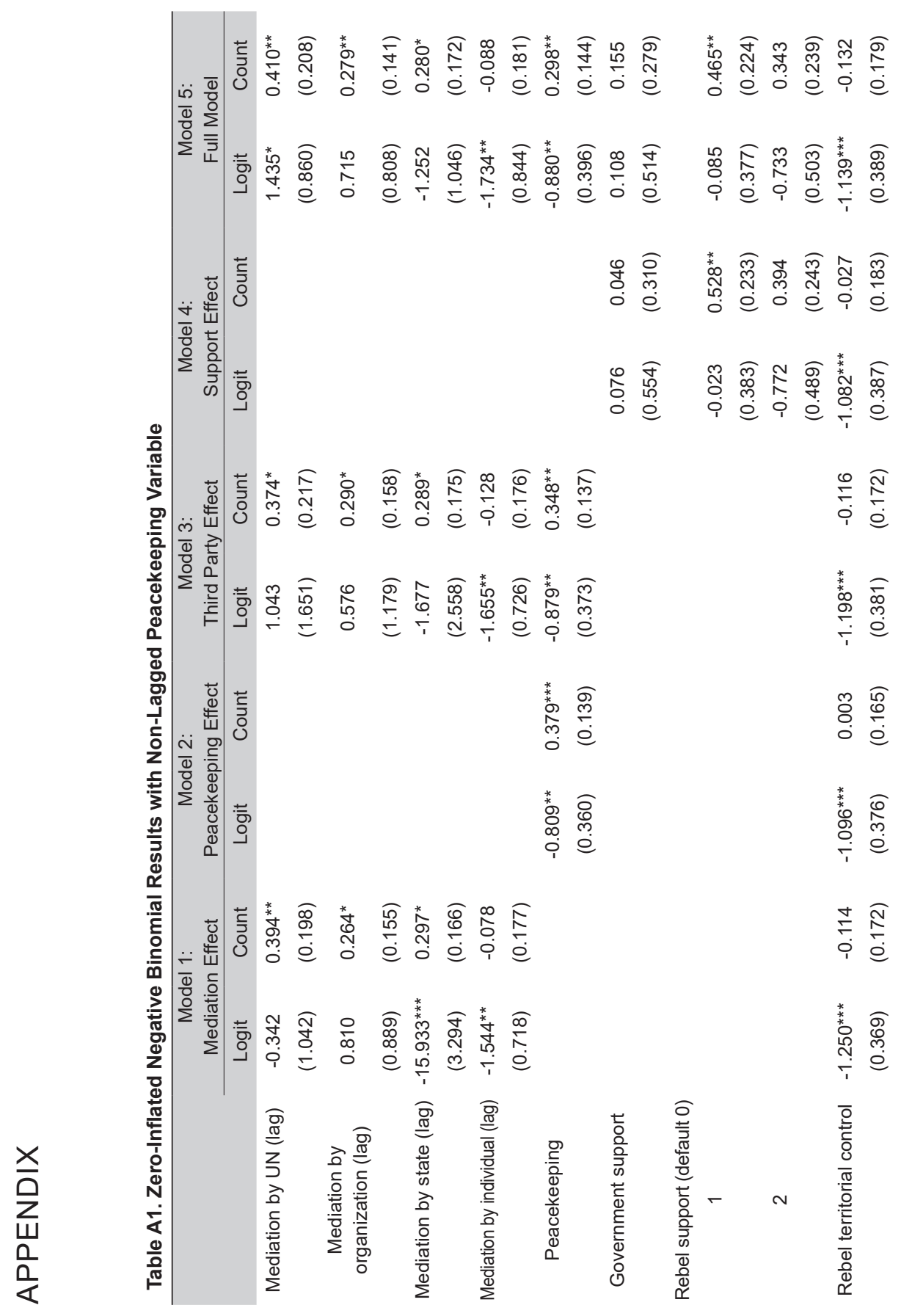




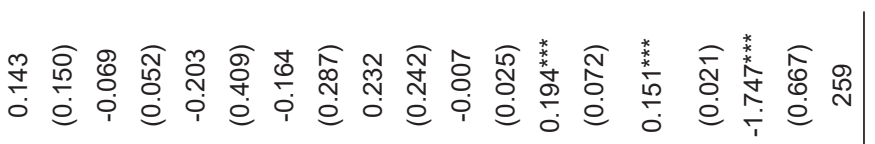

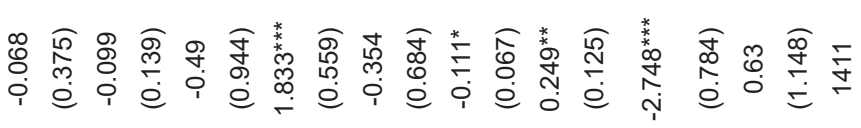

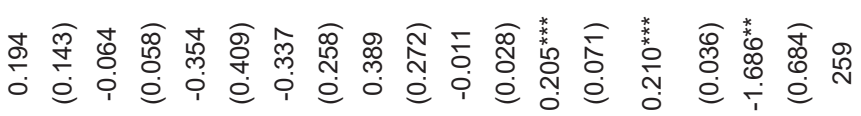

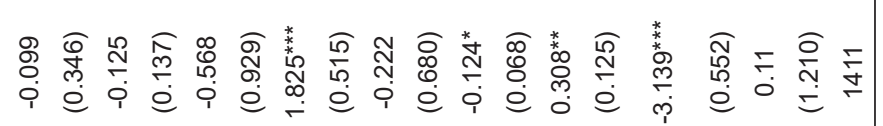

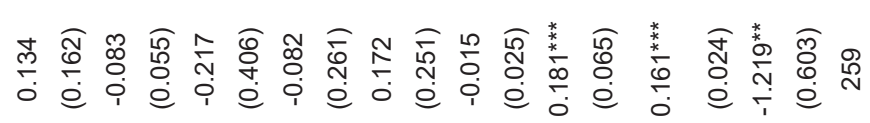

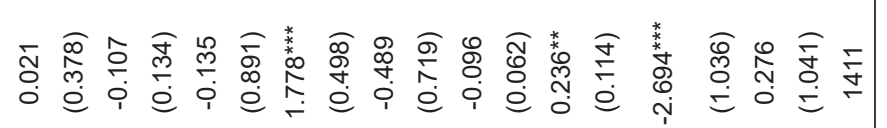

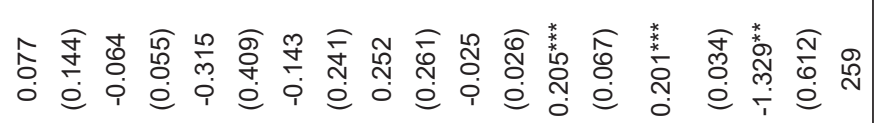

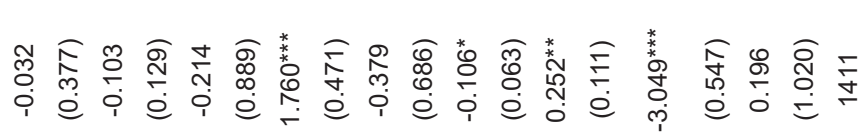

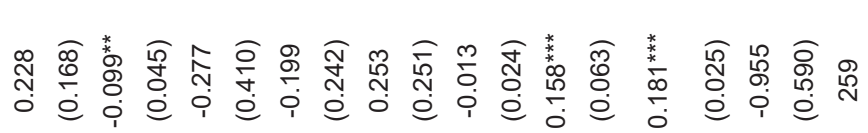

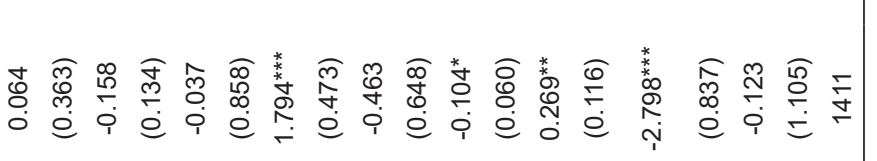

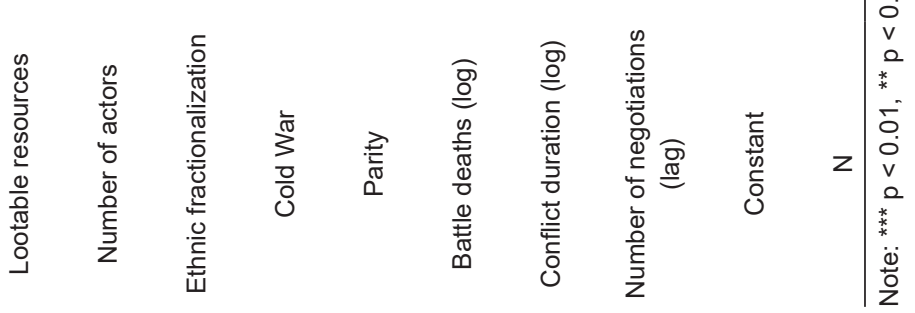


Enforcement Credibility and Frequency of Negotiations in Civil Wars | 263

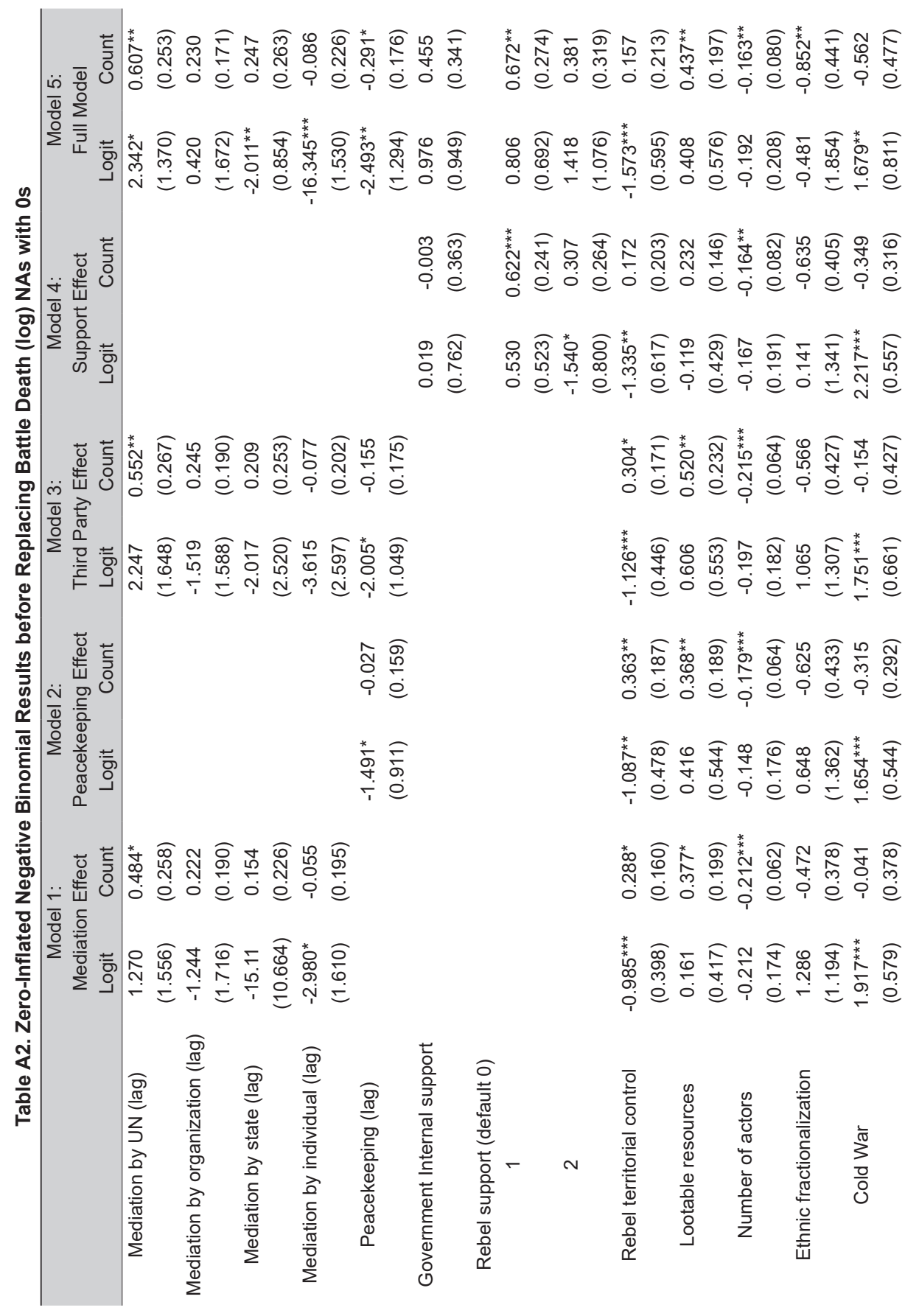




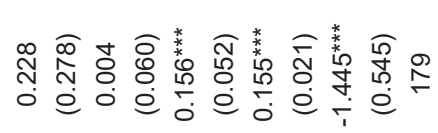

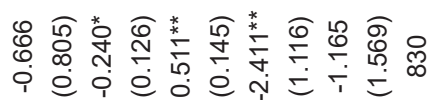

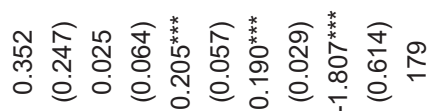

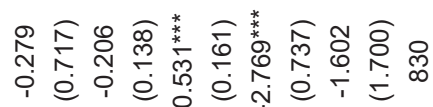

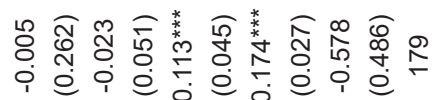

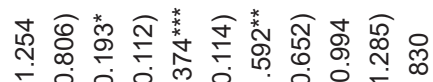
i

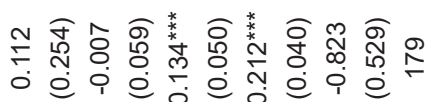

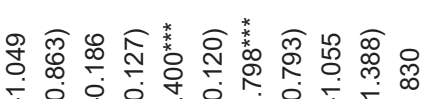

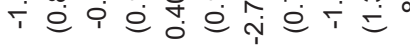

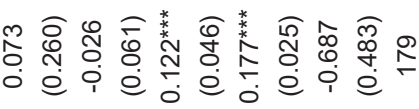

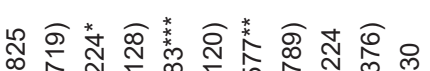
i.

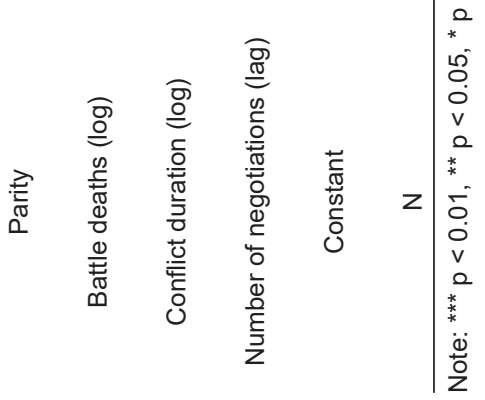


Enforcement Credibility and Frequency of Negotiations in Civil Wars | 265

Figure A1. Number of Negotiations by Rebel Support

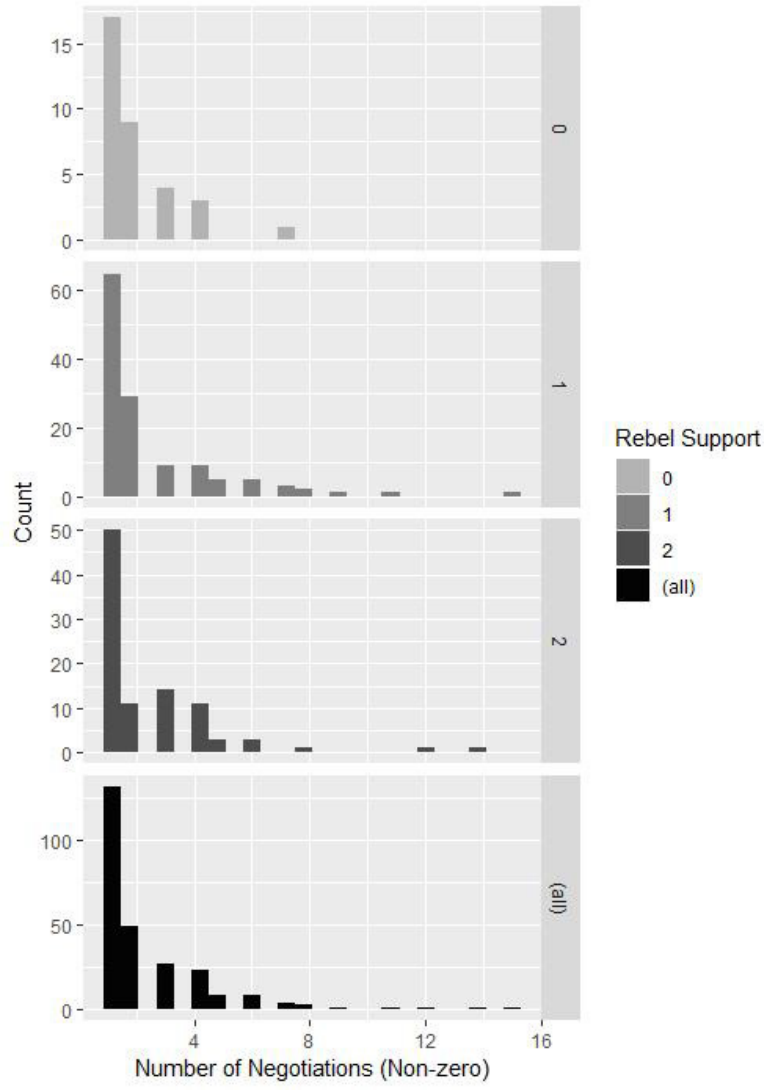


Figure A2. Number of Negotiations by Mediation and Peacekeeping Forces
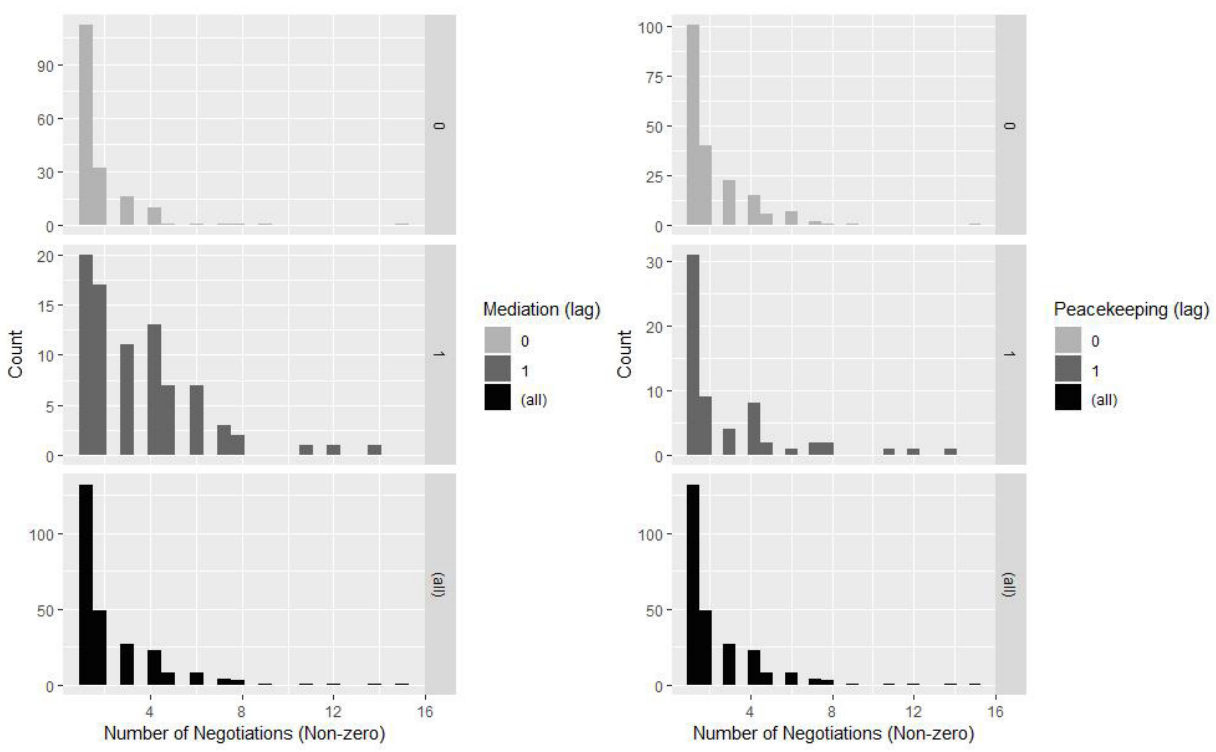

Figure A3.Correlation Matrix

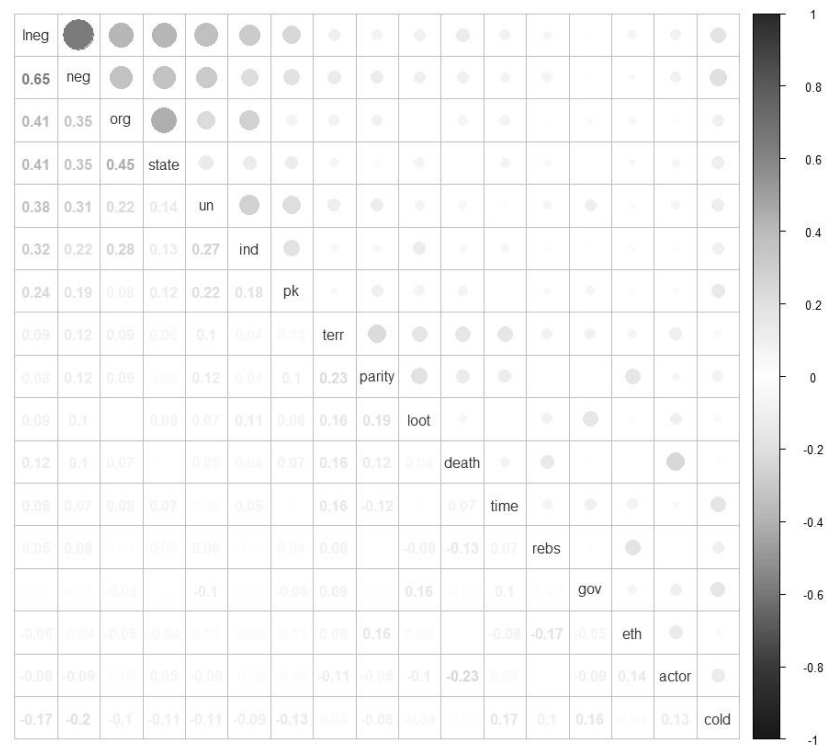

